\title{
An Evaluation of Quantitative and Probability-of-Precipitation Forecasts during the 1984-85 Warm and Cold Seasons
}

\author{
JOHN R. GYAKUM AND KATHERINE J. SAMUELS* \\ Department of Atmospheric Sciences, University of Illinois, Urbana, IL 61801 \\ (Manuscript received 3 October 1986, in final form 23 February 1987)
}

\begin{abstract}
Objective precipitation guidance has been evaluated for specific regions within the continental United States during the period 1984-85. Cold-season precipitation probability skills for seven locations range from $52 \%$ at 12-24 $\mathrm{h}$ forecast range to about $21 \%$ at $36-48 \mathrm{~h}$ range. While these skills show the probability forecasts to be generally useful, an examination of forecasts with an absolute error of greater than 0.5 reveals this smaller sample to contain a disproportionately large number of observed precipitating events. This suggests that largeerror-precipitation-probability forecasts have an unexpectedly large number of essentially unforecasted precipitation events, rather than false alarms. Warm-season precipitation probability skills are generally lower and show more variability within a given forecast range, with values ranging from 38 to $6 \%$ at 24-36 h range.

Limited-area Fine-Mesh (LFM) model, cold-season, quantitative precipitation forecasts (QPFs) for specific cities show no skill beyond a 12 -h forecast range. This loss of skill is associated with statistically significant overprediction of precipitation. However, to account for a coding error in the LFM model, we recomputed our statistics by halving all QPFs. The skills of these forecasts rose to respectable overall levels of $18.2,14.8,13.1$ and $4.0 \%$ for the respective forecast ranges of $0-12,12-24,24-36$ and 36-48 $\mathrm{h}$. These revised forecasts have eliminated all suggestion of precipitation overprediction, and instead show a systematic underprediction of precipitation.

Cold-season, area-averaged QPFs taken directly from the LFM show a loss of skill against the climatological control forecast beyond $24 \mathrm{~h}$. When we halved all forecasts, our area-averaged results showed, generally, more respectable overall skills of $9.3,20.8,16.9$ and $5.2 \%$ for the respective forecast ranges.

Warm-season point and area-averaged QPFs show no skill against the climatological control forecast for any of the four forecast ranges out to $48 \mathrm{~h}$. Statistically significant precipitation underprediction is found for the raw warm season QPFs. When the forecasts are halved, the skills deteriorate to even lower values and systematic underprediction of precipitation is more prevalent.
\end{abstract}

\section{Introduction}

The purpose of this paper is to assess recent objective precipitation guidance for selected regions of the continental United States. In spite of large-scale $500 \mathrm{mb}$ circulation prognoses showing generally acceptable reliability and continuing improvement (Bengtsson, 1985), progress in translating this midtropospheric success into useful objective precipitation forecasts has been small (Sanders, 1979, 1986; Charba and Klein, 1980; Ramage, 1982; Bosart, 1983). However, studies by Glahn (1985) and Murphy and Sabin (1986) have suggested recent improvement in National Weather Service precipitation forecasting nationwide.

Bosart (1980) has assessed the quality of operational quantitative precipitation forecasts produced by the National Meteorological Center's (NMC's) LimitedArea Fine-Mesh (LFM) model (Gerrity, 1977; Newell and Deaven, 1981) for southern and central New England. He found that the objective forecasts of pre-

* Current address: Prairie View, IL 60069. cipitation on an area-averaged basis lost to a climatological control beyond a $24-\mathrm{h}$ forecast range. We will approach the problem by evaluating precipitation probability and quantitative precipitation forecasts for selected cities and regions for both the warm and cold seasons during 1984 and 1985 . The methodology and description of data sets are shown in section 2. Section 3 discusses precipitation climatologies for representative stations within each region. Precipitation probability and quantitative forecast results are shown in sections 4 and 5, respectively. A concluding discussion follows in section 6 .

\section{Methodology and data sets}

LFM quantitative precipitation forecasts (QPFs) continue to be operationally produced as part of NMC's Early Analysis and Forecast System. Though NMC has recently introduced a new operational model in the Regional Analysis and Forecast System (Hoke et al., 1985), the LFM will continue to be used for the near future in generating model output statistics (MOS) forecasts (Klein and Lewis, 1970). Therefore, its guid- 
ance will still have impact in the operational forecast environment.

LFM precipitation forecasts for the cities shown in Fig. 1 were derived from the $12-h_{1}$ transmissions of LFM output (FOUS) found on the Federal Aviation Administration-604 line. Station names associated with each three-character identifier used in this text are listed in Table 1 . While all stations shown in Table 1 routinely

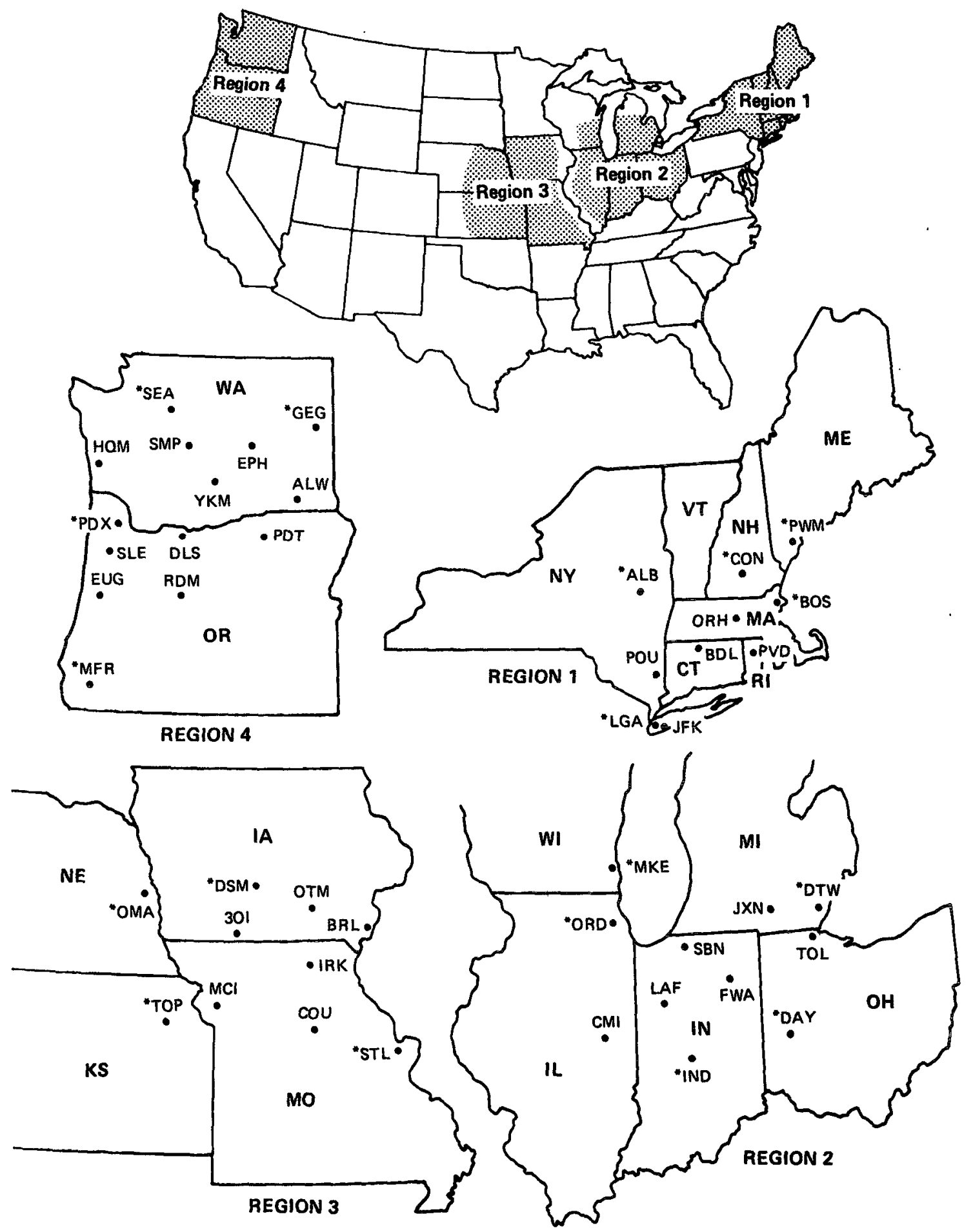

FIG. 1. Four regions of the United States considered in this study, along with locations of verification stations. Those locations shown with an asterisk are also LFM FOUS precipitation forecast stations. 
TABLE 1. List of stations (and three-character identifiers) considered in this study.

\begin{tabular}{ll}
\hline \hline ALB (Albany, NY) & MCI (Kansas City, MO) \\
ALW (Walla Walla, WA) & MFR (Medford, OR) \\
BDL (Hartford, CT) & MKE (Milwaukee, WI) \\
BOS (Boston, MA) & OMA (Omaha, NE) \\
BRL (Burlington, IA) & ORD (Chicago, IL) \\
CMI (Champaign, IL) & ORH (Worcester, MA) \\
CON (Concord, NH) & OTM (Ottumwa, IA) \\
COU (Columbia, MO) & PDT (Pendleton, OR) \\
DAY (Dayton, OH) & PDX (Portland, OR) \\
DLS (The Dalles, OR) & POU (Poughkeepsie, NY) \\
DSM (Des Moines, IA) & PVD (Providence, RI) \\
DTW (Detroit, MI) & PWM (Portland, ME) \\
EPH (Ephrata, WA) & RDM (Redmond, OR) \\
EUG (Eugene, OR) & SBN (South Bend, IN) \\
FWA (Fort Wayne, IN) & SEA (Seattle, WA) \\
GEG (Spokane, WA) & SLE (Salem, OR) \\
HQM (Hoquiam, WA) & SMP (Stampede Pass, WA) \\
IND (Indianapolis, IN) & STL (Saint Louis, MO) \\
IRK (Kirksille, MO) & TOL (Toledo, OH) \\
JFK (New York City, & TOP (Topeka, KS) \\
NY; Kennedy Airport) & YKM (Yakima, WA) \\
JXN (Jackson, MI) & 3OI (Lamoni, IA) \\
LAF (Lafayette, IN) & \\
LGA (New York City, & \\
NY; La Guardia Airport) & \\
\hline
\end{tabular}

transmit 6-h precipitation amounts, Fig. 1 shows only 18 of these stations to be LFM FOUS forecast locations. Each of these 18 locations will be used to compare area-averaged forecasts with observed area-averaged precipitation amounts derived from the 45 reporting stations listed in Table 1. A direct comparison will be made between LFM QPFs and verifications at eight point locations: Boston, Albany, Dayton, Chicago, St. Louis, Des Moines, Seattle and Spokane. Although it is strictly incorrect to verify model precipitation forecasts with point precipitation amounts, a large sample of observations is used so that representative results should be found in the absence of any significant local effects.

The quantitative precipitation results will be used for only that sample of cases in which a measurable amount of precipitation falls within the given time period at the given station for point verifications, and at a minimum of three verification locations for the areaaveraged calculations. This conditional verification scheme essentially poses the question, "How much precipitation falls, given that a measurable amount falls?" The simpler task of separating measurable precipitation days from dry days will be discussed later in this section.

The LFM forecasts and verifications are divided into categories of approximately $1.0 \mathrm{~mm}$, beginning with the measurable precipitation threshold of $0.25 \mathrm{~mm}$. The error in the precipitation amount is the absolute value of the difference between the forecast and observed values. The skill, SK, of a forecast with respect to a control forecast is defined as

$$
\operatorname{SK}(\%)=\frac{\sum E_{C L}-\sum E_{F O}}{\sum E_{C L}} \times 100,
$$

where the summations denote the number of forecasts considered, and $E_{C L}$ and $E_{F O}$ are, respectively, the absolute values of the climatology and forecast errors. The climatology forecast is the control against which the forecasts will be measured. This control forecast is the long-term median value found on days of measurable precipitation. The precipitation climatologies of the different regions will be discussed in the next section. Forecasts of precipitation amounts are verified not only by season and location, but also according to one of four 12-h forecast ranges out to $48 \mathrm{~h}: 0-12,12-$ $24,24-36$ and $36-48 \mathrm{~h}$.

To investigate the skill of the probability of measurable precipitation forecasts, we will use the point verifications and forecasts for Boston, Dayton, Chicago, St. Louis, Des Moines, Seattle, and Spokane. These point probability forecasts are routinely issued every $12 \mathrm{~h}$ as part of the FOUS transmissions, based upon MOS guidance, which is, in turn, based upon LFM model output. The forecast intervals to be used in this study are $12-24,24-36$ and $36-48 \mathrm{~h}$.

Error points for precipitation probability forecasts are computed according to Brier (1950) as

$$
\sum E_{F O}=\frac{1}{N}\left[\sum_{i=1}^{N}\left(F_{i}-V_{i}\right)^{2}\right]
$$

where the forecast error points are summed over the number of forecasts, $N . F_{i}$ and $V_{i}$ represent, respectively, the $i$ th forecast and verification. The verification value, $V$, has the value 1 if measurable precipitation occurred, and 0 otherwise. The error points computed in (2) are applied to the probability forecast and to the climatological control forecast. These values are used in expression (1) to compute the skill of the precipitation probability forecast.

The climatology forecasts are based upon long-term frequency of measurable precipitation days occurring in a given month for a given station.

\section{Precipitation climatologies}

Long-term climatological values of precipitation frequency and median precipitation amounts are shown in Table 2 for each city used in the climatological control forecasts. The six months listed included June and July for the warm season, and November through February for the cold season. These climatologies are based upon daily precipitation data for each city from 1963 through 1983 as tabulated in the U.S. Commerce Department state climatological data publications (NOAA, 1963-83). The median precipitation amount is used for each city in evaluating point and area-averaged QPFs. Median precipitation data for 1942-83 were kindly furnished to us by Professor Lance 
TABLE 2. Climatological values used in the calculation of skill for quantitative precipitation forecasts (QPF) and precipitation probabilities (POP). The QPF and POP numbers are median values (mm) and frequencies (\%), respectively. These climatologies are based upon 1963-1983 data for all cities except Albany in which 1942-1983 data were used. No calculation was performed for Albany's POP forecasts.

\begin{tabular}{lrrrrrr}
\hline Station & Jan & Feb & June & July & Nov & Dec \\
\hline BOS QPF (mm) & 4 & 3 & 4 & 4 & 5 & 4 \\
POP (\%) & 37 & 35 & 35 & 28 & 37 & 40 \\
ALB QPF (mm) & 2 & 3 & 4 & 3 & 3 & 3 \\
ORD QPF (mm) & 2 & 2 & 6 & 5 & 3 & 2 \\
POP (\%) & 38 & 32 & 34 & 31 & 35 & 37 \\
DAY QPF (mm) & 2 & 2 & 6 & 4 & 3 & 3 \\
POP (\%) & 41 & 34 & 34 & 33 & 36 & 38 \\
DSM QPF (mm) & 1 & 2 & 6 & 4 & 3 & 2 \\
POP (\%) & 27 & 17 & 34 & 30 & 25 & 27 \\
STL QPF (mm) & 2 & 2 & 5 & 6 & 4 & 2 \\
POP (\%) & 28 & 27 & 31 & 28 & 30 & 32 \\
SEA QPF (mm) & 5 & 4 & 3 & 3 & 5 & 5 \\
POP (\%) & 57 & 52 & 19 & 18 & 57 & 65 \\
GEG QPF (mm) & 3 & 2 & 2 & 2 & 2 & 3 \\
POP (\%) & 45 & 37 & 27 & 14 & 41 & 50 \\
\hline
\end{tabular}

Bosart of the State University of New York at Albany. The area-averaged climatological control forecasts are the arithmetic averages of the two cities found in each of the four regions. The climatological probability forecasts are the monthly frequencies of days on which a measurable amount of precipitation occurs.

A substantial warm-season peak in median precipitation is found at the four continental locations of Chicago, Dayton, Des Moines, and St. Louis. This is due to the relatively high number of heavy precipitation events occurring during the summer, most of which are convective. The preponderance of convective activity for the continental location of Urbana, Illinois has recently been shown by Gyakum (1986). The relatively uniform annual precipitation frequency of six locations contrasts sharply with the northwest locations of Seattle and Spokane, in which at least one-half of the days in winter are marked by measurable precipitation and less than one-quarter of the days are rainy during the summer.

\section{Precipitation probability forecast results}

We assessed the point precipitation probability forecasts produced by the MOS products (Klein and Lewis, 1970) for seven cities by applying the Brier score [Eq. (2)] to the skill equation (1). The results for the cold and warm seasons are shown in Figs. 2 and 3, respectively. These skill scores are generally higher during the cold season, with a downward trend in skill with increasing forecast range. Nonnegligible positive skills are shown for both seasons, although more variance between cities is seen during the warm season. This

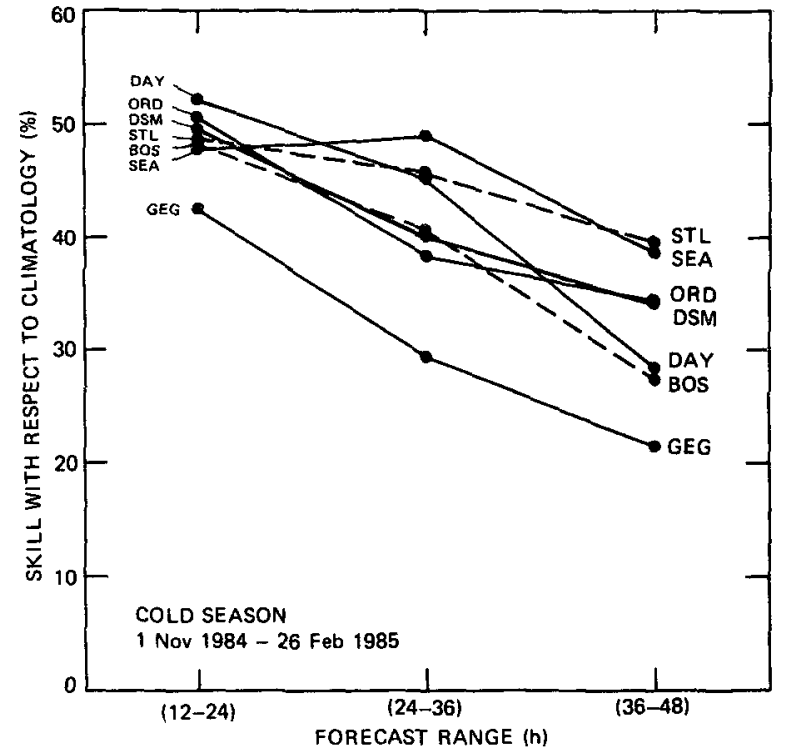

FIG. 2, Point precipitation probability forecast skills for the seven cities shown, and for the three forecast ranges of 12-24, 24-36, and $36-48 \mathrm{~h}$. Data are taken from the cold season of 1 November 198426 February 1985.

may be due to the smaller sample of warm-season cases. The number of forecasts examined for each city and for each forecast range was approximately 170 for the cold season and 55 for the warm season.

The skills reported here for predicting whether measurable precipitation will occur are comparable to those found by Bosart (1983) and Sanders (1986) for several years duration at the specific locations of Albany, New York, and Boston, Massachusetts, respectively.

Figure 4 shows the time evolution of $12-24 \mathrm{~h}$ pre-

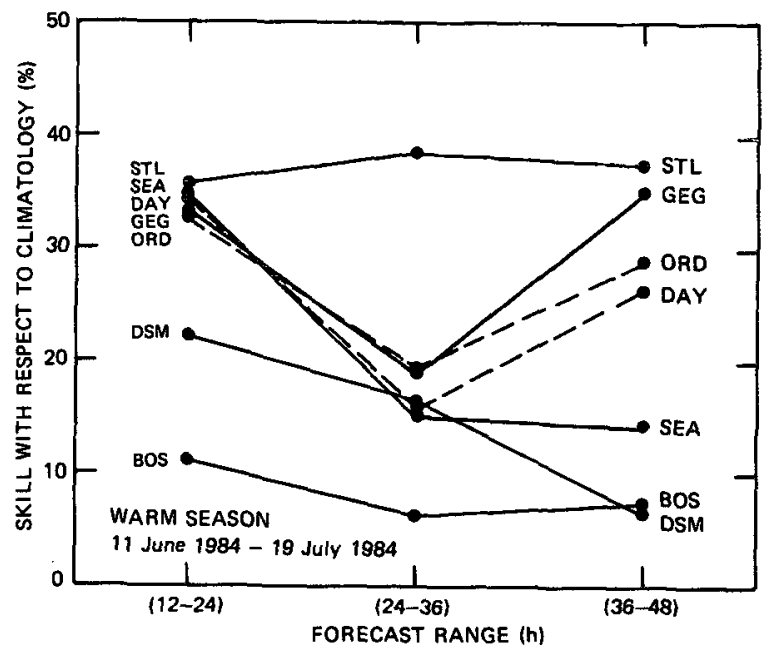

FIG. 3. As in Fig. 2 except for the warm season of 11 June-19 July 1984. 


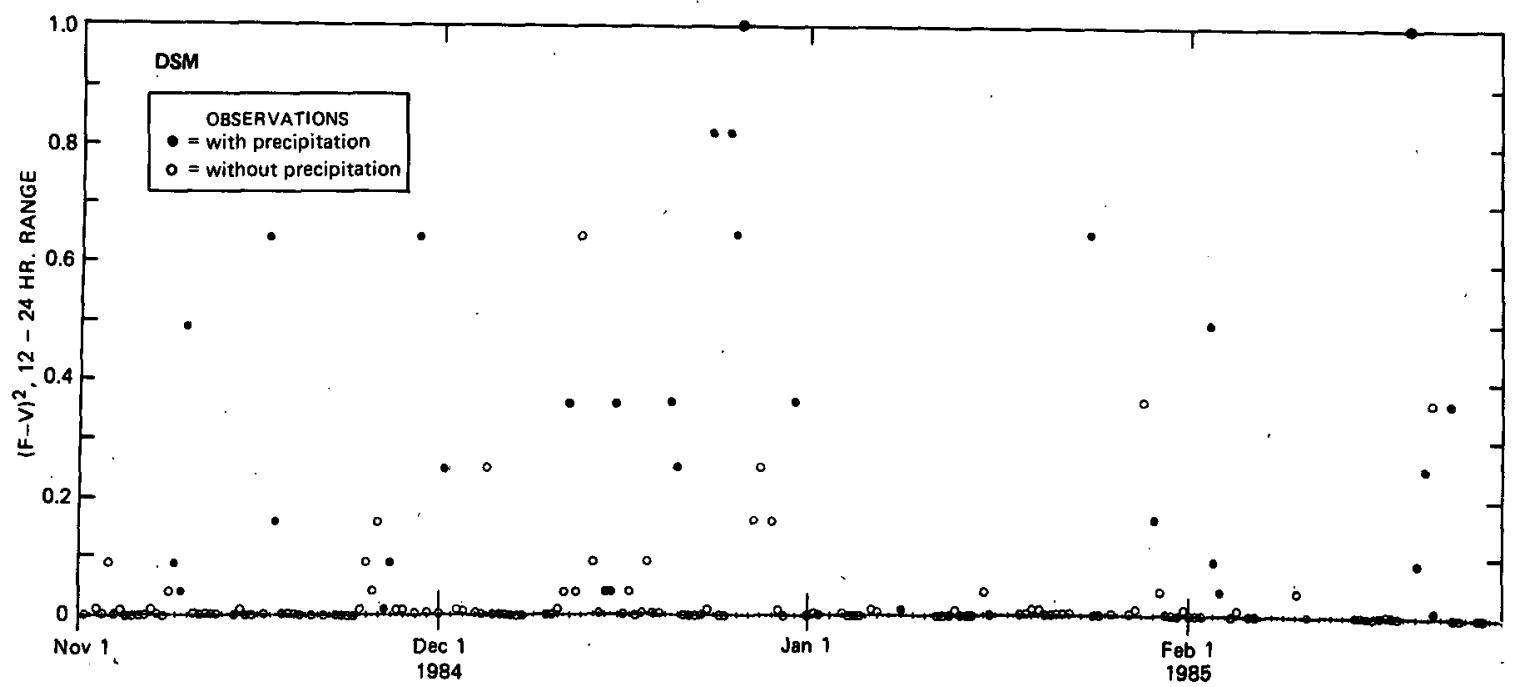

FIG. 4. A time evolution of squared precipitation probability errors $(F-V)^{2}$, as defined in Eq. (2) for Des Moines, Iowa, from 1 November 1984-26 February 1985 for the 12-24 h forecast range. Darkened circles represent an observed measurable precipitation event, and open circles show an observed dry event.

Figure 4 shows the time evolution of 12-24 h precipitation probability forecast errors for Des Moines, Iowa, during the cold season. While the majority of the squared errors are less than 0.25 , a substantial minority of cases occurred with much larger errors. It also appears that a disproportionate share of these poorly forecasted cases are observed precipitation events.

To investigate these precipitation probability errors, we present Table 3 which shows the cold-season statistics of each of the seven cities. The total number of 12-h periods for which we have precipitation data exceeds 200 for each station. Missing forecasts reduced that number to about 170 for forecast verification. We arbitrarily defined a large error precipitation probability forecast as one in which the absolute difference between the forecast and verification exceeds 0.5 , or in which the square of the error exceeds 0.25 . The number of such events, $N$, is shown in Table 3 for each city. The expected number of measurable precipitation events in these large error forecasts (column 3 ) is the product of the measurable precipitation frequency, $P$, and the number of large error forecasts, $N$. All cities show substantially more measurable precipitation events in the large error forecasts than expected. To investigate whether these actual values are significantly greater than anticipated, we found the probability of obtaining these actual values from a normal distribution with a mean of $N P$, and a standard deviation of $[N P(1-P)]^{1 / 2}$ (Panofsky and Brier, 1968). Since the sample of large error forecasts is sufficiently large such that the standard deviation exceeds 3.0, a normal distribution may be assumed. The probability of finding as many rainy events as we did is substantially less than $0.01 \%$ for all cities except for Seattle, where the probability was about $2 \%$.

Thus, the majority of precipitation probability forecasts are excellent, and our statistics are dominated by these well-forecasted dry events. However, an examination of the large error forecasts reveals an unexpectedly large number of observed precipitating events. This suggests a relatively large number of essentially

TABLE 3. Cold-season precipitation probability statistics.

\begin{tabular}{|c|c|c|c|c|c|}
\hline & $\begin{array}{c}\text { Number of measurable } \\
\text { precipitation } \\
\text { events/total } \\
(P)\end{array}$ & $\begin{array}{c}\text { Number of events with } \\
(\mathrm{F}-\mathrm{V})^{2}>0.25 \\
(N)\end{array}$ & $\begin{array}{l}\text { Expected number of } \\
\text { measurable events } \\
\text { in poor forecasts }\end{array}$ & $\begin{array}{c}\text { Actual } \\
\text { number }\end{array}$ & $\begin{array}{c}\text { Probability of } \\
\text { actual number } \\
(\%)\end{array}$ \\
\hline BOS & $39 / 203$ & 62 & 11.9 & $29^{\circ}$ & $<0.01$ \\
\hline ORD & $48 / 202$ & 64 & 15.2 & 43 & $<0.01$ \\
\hline DAY & $69 / 207$ & 84 & 28.0 & 69 & $<0.01$ \\
\hline DSM & $45 / 206$ & 61 & 13.3 & 55 & $<0.01$ \\
\hline STL & $49 / 212$ & 54 & 12.5 & 43 & $<0.01$ \\
\hline SEA & $60 / 206$ & 87 & 25.3 & 34 & $\approx 2.1$ \\
\hline GEG & $58 / 207$ & 94 & 26.3 & 89 & $<0.01$ \\
\hline
\end{tabular}


unforecasted precipitation events rather than false alarms of forecasted precipitation.

\section{Quantitative precipitation forecast results}

We have evaluated the raw quantitative precipitation forecasts taken from the LFM FOUS output for the eight cities listed in Table 2. Precipitation forecast category errors for both the climatological control and FOUS forecasts and skills were computed from Eq. (1) for each of four 12 -h forecast ranges to $48 \mathrm{~h}$. Figure 5 shows the results of these calculations for the cold season of 1 November 1984-26 February 1985. Clearly, all of these forecasts lose to climatology beyond the $0-$ $12 \mathrm{~h}$ range. Bosart (1980) has reported average LFM2 skills of -7.2 and $-21.9 \%$ for the respective forecast ranges of 12-24 and 24-36 h during the first 4.5 months of 1979 for five northeast United States stations. Our results show lower skills for a slightly larger sample of stations spaced over different regions of the United

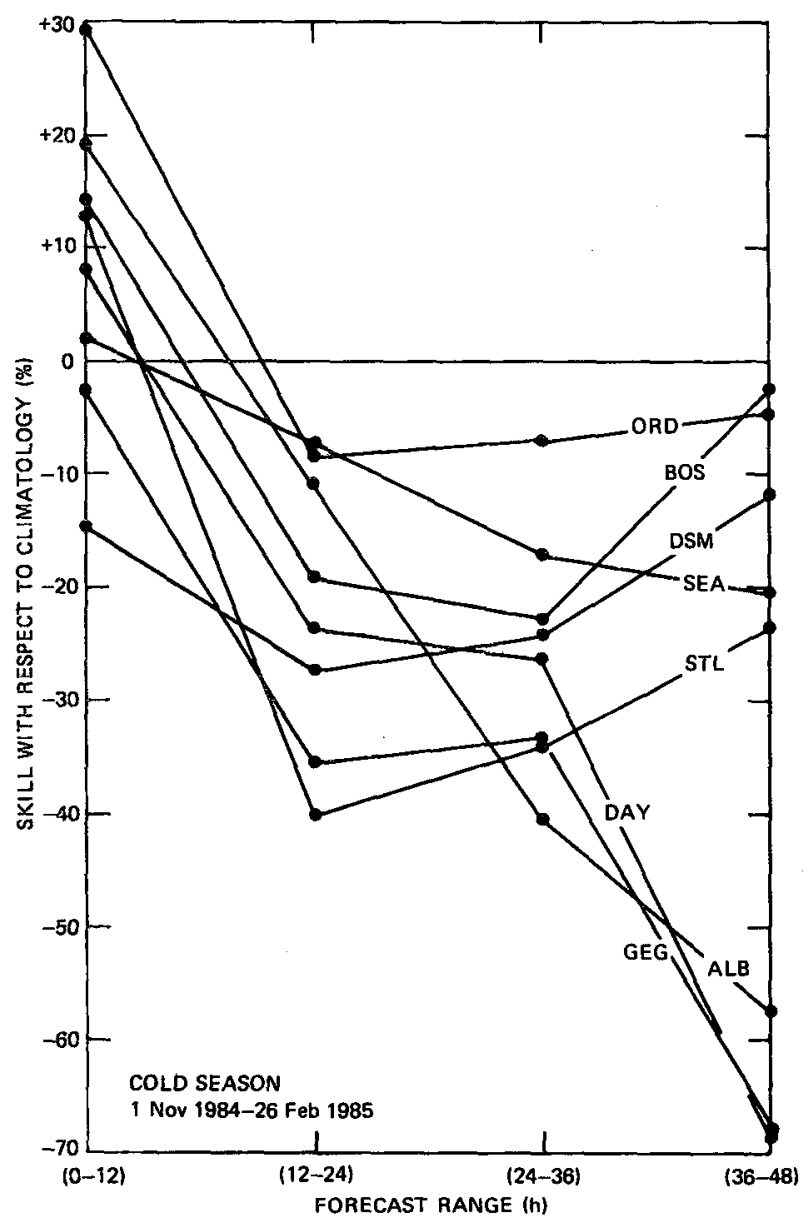

FIG. 5. Quantitative precipitation forecast skills for the eight cities shown, and for the four forecast ranges of $0-12,12-24,24-36$, and $36-48 \mathrm{~h}$. Forecasts are taken from LFM FOUS output for the cold season of 1 November 1984-26 February 1985.
States. Bosart (1980) has suggested that much of the loss of predictive skill in the LFM model forecasts is the result of a systematic overprediction of precipitation accompanying major cyclonic events. Indeed, an examination of forecast biases in this sample (Table 4) shows 10 of the 32 forecasts have, at the $95 \%$ confidence level using the Student's t-test, an algebraic error significantly different from zero. All ten of these categories show a statistically significant overprediction of precipitation.

While the preceding results show little usefulness in these QPFs, a coding error in the LFM precipitation algorithm (Phillips, 1985) at NMC has produced all precipitation forecasts to be twice the quantity actually forecasted by the model. However, all displays of the LFM QPFs continue to include this error because the MOS products are based, in part, upon these precipitation forecasts. Nevertheless, we halved all quantitative precipitation forecasts in our sample and repeated our exercises of computing skill scores and biases for each of the eight cities. A comparison of Figs. 5 and 6 shows the dramatic improvement in skill scores in the former figure simply as a consequence of halving the precipitation forecast. While the results of Fig. 6 are not as distinguished as those found for the point precipitation probability forecasts (Fig. 2), gains against the climatological control forecast are found at all forecast ranges out to $48 \mathrm{~h}$ for virtually all cities. Table 5 summarizes the point QPF errors for each forecast range for both the raw forecasts and for the halved QPFs. There is a substantial reduction in forecast errors and enhancement in skill against the climatological control forecast simply occurring as a result of dividing the precipitation forecasts by two.

Table 4 shows the forecast biases in these halved precipitation forecasts. As might have been expected, the systematic overpredictions found in the raw LFM forecasts in Table 4 have been eliminated. Instead, at the $95 \%$ confidence level, 14 of the 32 categories show a statistically significant underprediction of precipitation.

The area-averaged precipitation results (Fig. 7) show a loss of skill against the climatological control forecast beyond $24 \mathrm{~h}$. Although this is a slight improvement beyond the overall point precipitation results (Fig. 5), these results still appear comparably disappointing to Bosart's (1980) area-averaged QPF results of 18.5 and $-7.4 \%$ for the $12-24$ and $24-36 \mathrm{~h}$ forecasts, respectively. However, the skills associated with the halved and area-averaged precipitation forecasts (Fig. 8) show considerable improvement over comparable results shown by Bosart and by Fig. 7. In fact, the overall areaaveraged results, when compared with the overall point results (Table 5), show improvement in all categories except for the 0-12 h halved QPF category.

While the area-averaged QPFs do show improved skills over comparable point QPFs, there is more of a dry bias in the area-averaged forecasts. The raw area- 
TABLE 4. Number $(N)$, mean, and standard deviation of cold-season QPF errors (forecast minus observed) for the city and forecast range listed. Results are shown for both raw and halved LFM QPFs. The units of the mean and standard deviation are in precipitation categories defined in the text. Asterisk (*) indicates the sample mean forecast error is significantly different from zero, at the $95 \%$ confidence level.

\begin{tabular}{|c|c|c|c|c|c|c|}
\hline \multirow[b]{2}{*}{ Station } & \multirow[b]{2}{*}{$\begin{array}{l}\text { Forecast } \\
\text { range (h) }\end{array}$} & \multirow[b]{2}{*}{$N$} & \multicolumn{2}{|c|}{ Raw precipitation forecasts } & \multicolumn{2}{|c|}{$\begin{array}{l}\text { Precipitation forecasts divided } \\
\text { by two }\end{array}$} \\
\hline & & & Mean & $\begin{array}{l}\text { Standard } \\
\text { deviation }\end{array}$ & Mean & $\begin{array}{l}\text { Standard } \\
\text { deviation }\end{array}$ \\
\hline BOS & $\begin{array}{r}0-12 \\
12-24 \\
24-36 \\
36-48\end{array}$ & $\begin{array}{l}39 \\
39 \\
38 \\
37\end{array}$ & $\begin{array}{r}-0.2 \\
* 1.7 \\
1.5 \\
1.2\end{array}$ & $\begin{array}{l}3.5 \\
4.3 \\
4.9 \\
5.5\end{array}$ & $\begin{array}{r}*-1.6 \\
-0.7 \\
-0.9 \\
-1.1\end{array}$ & $\begin{array}{l}2.7 \\
2.9 \\
3.8 \\
3.5\end{array}$ \\
\hline ALB & $\begin{array}{r}0-12 \\
12-24 \\
24-36 \\
36-48\end{array}$ & $\begin{array}{l}45 \\
44 \\
45 \\
44\end{array}$ & $\begin{array}{r}0.4 \\
* 1.3 \\
* 2.0 \\
* 1.9\end{array}$ & $\begin{array}{l}3.5 \\
3.9 \\
4.9 \\
5.4\end{array}$ & $\begin{array}{r}*-1.0 \\
-0.5 \\
-0.2 \\
-0.2\end{array}$ & $\begin{array}{l}2.4 \\
2.3 \\
3.0 \\
3.4\end{array}$ \\
\hline ORD & $\begin{array}{r}0-12 \\
12-24 \\
24-36 \\
36-48\end{array}$ & $\begin{array}{l}42 \\
40 \\
42 \\
44\end{array}$ & $\begin{array}{r}-0.7 \\
1.8 \\
1.1 \\
-0.6\end{array}$ & $\begin{array}{l}4.9 \\
5.6 \\
5.8 \\
5.4\end{array}$ & $\begin{array}{r}*-2.4 \\
-1.1 \\
*-1.3 \\
*-2.1\end{array}$ & $\begin{array}{l}4.7 \\
4.2 \\
4.0 \\
4.9\end{array}$ \\
\hline DAY & $\begin{array}{r}0-12 \\
12-24 \\
24-36 \\
36-48\end{array}$ & $\begin{array}{l}65 \\
65 \\
63 \\
63\end{array}$ & $\begin{array}{r}0.0 \\
* 1.2 \\
* 1.3 \\
1.3\end{array}$ & $\begin{array}{l}3.4 \\
4.4 \\
4.0 \\
5.7\end{array}$ & $\begin{array}{r}*-1.3 \\
-0.7 \\
-0.6 \\
-0.5\end{array}$ & $\begin{array}{l}3.0 \\
3.2 \\
2.9 \\
3.8\end{array}$ \\
\hline DSM & $\begin{array}{r}0-12 \\
12-24 \\
24-36 \\
36-48\end{array}$ & $\begin{array}{l}42 \\
39 \\
42 \\
42\end{array}$ & $\begin{array}{r}-0.1 \\
1.1 \\
1.0 \\
0.0\end{array}$ & $\begin{array}{l}3.6 \\
4.5 \\
4.3 \\
4.2\end{array}$ & $\begin{array}{r}*-1.2 \\
-0.6 \\
-0.7 \\
*-1.2\end{array}$ & $\begin{array}{l}3.0 \\
3.1 \\
3.2 \\
3.3\end{array}$ \\
\hline STL & $\begin{array}{r}0-12 \\
12-24 \\
24-36 \\
36-48\end{array}$ & $\begin{array}{l}48 \\
46 \\
44 \\
44\end{array}$ & $\begin{array}{r}-0.9 \\
1.9 \\
1.4 \\
-0.1\end{array}$ & $\begin{array}{l}5.0 \\
7.8 \\
6.9 \\
7.0\end{array}$ & $\begin{array}{r}*-2.8 \\
-1.3 \\
-1.5 \\
*-2.2\end{array}$ & $\begin{array}{l}5.0 \\
5.6 \\
5.4 \\
5.6\end{array}$ \\
\hline SEA & $\begin{array}{r}0-12 \\
12-24 \\
24-36 \\
36-48\end{array}$ & $\begin{array}{l}59 \\
55 \\
56 \\
54\end{array}$ & $\begin{array}{r}-0.7 \\
0.1 \\
0.5 \\
0.3\end{array}$ & $\begin{array}{l}5.1 \\
5.5 \\
5.8 \\
7.2\end{array}$ & $\begin{array}{l}*-2.6 \\
*-2.2 \\
*-1.9 \\
*-1.9\end{array}$ & $\begin{array}{l}4.5 \\
4.7 \\
4.6 \\
5.1\end{array}$ \\
\hline GEG & $\begin{array}{r}0-12 \\
12-24 \\
24-36 \\
36-48\end{array}$ & $\begin{array}{l}57 \\
54 \\
52 \\
51\end{array}$ & $\begin{array}{l}* 1.0 \\
* 2.0 \\
* 1.5 \\
* 2.0\end{array}$ & $\begin{array}{l}2.8 \\
3.0 \\
3.2 \\
5.6\end{array}$ & $\begin{array}{r}-0.5 \\
0.1 \\
-0.3 \\
0.1\end{array}$ & $\begin{array}{l}2.3 \\
1.7 \\
2.6 \\
3.5\end{array}$ \\
\hline
\end{tabular}

averaged QPFs show a mean algebraic forecast error of +0.3 precipitation categories, while the point $\mathrm{QPFs}$ showed a mean error of +0.8 precipitation categories (Table 4). The four regions and four forecast ranges combine for 16 forecast classes. Three of these classes show a significant precipitation overprediction (by the criterion seen in Table 4), and three show significantly underforecast precipitation in the raw area-averaged QPFs. This compares with 10 out of 32 classes showing a significant precipitation overprediction in the raw point QPFs (Table 4). While 14 out of 32 classes show a significant precipitation underprediction in the halved point QPFs (Table 4), 14 out of the 16 cases show comparable underprediction in the halved area-averaged QPFs.

The considerably smaller summer sample of point quantitative precipitation forecast skills is summarized in Table 6. The raw precipitation forecasts produce comparably poor skills to those found for the cold sea- son (Table 5), except that the 0-12 h warm-season forecasts show a lower skill. What distinguishes the summer sample from that for the winter season is that when the forecasts are halved, the summer skill levels do not improve to a positive (or useful) level. Unlike the cold-season area-averaged results (Table 5), Table 6 shows a deterioration in the overall skills of areaaveraged forecasts versus the comparable summer point QPFs.

Some insight into fundamental differences between the cold- and warm-season forecasts may be gleaned from Table 7, which shows the summer QPF biases for each city and forecast range. Virtually all forecast categories show underforecasts of precipitation, with six categories indicating statistically significant negative biases. This is opposite to comparable results found for the cold season (Table 4) in which all statistically significant biases involved overprediction of precipitation. Naturally, when all of the precipitation forecasts 


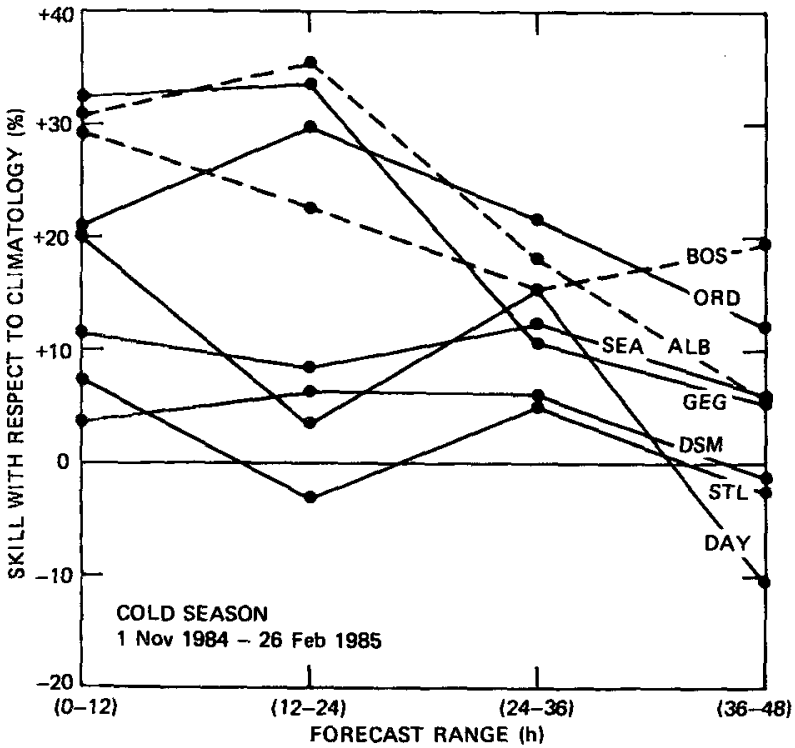

FIG. 6. As in Fig. 5 except the forecasted precipitation amounts have been halved.

are halved, more of a systematic underprediction of precipitation appears and, since the absolute errors increase while the control forecast errors remain constant, the forecast skills deteriorate. Similar but stronger indications of statistically significant negative biases are found for the area-averaged summer precipitation forecasts. Ten of the 16 raw QPF classifications show statistically significant area-averaged precipitation underpredictions and 13 of the 16 halved area-averaged precipitation predictions showed this same significant underprediction.

Thus, all of the warm-season quantitative precipitation forecasts lose to the climatological control. Our results also show this loss of skill to be associated with the LFM's tendency to underpredict warm-season precipitation events. It is speculated that the more prominent appearance of convection during the warm season in all regions contributed to this lack of skill.

\section{Conclusions}

We have examined LFM-produced precipitation forecasts for climatologically representative cities and areas of the conterminous United States. Point precipitation probability forecasts show skills ranging to above $50 \%$ at $12-24 \mathrm{~h}$ to slightly above $20 \%$ at $36-48 \mathrm{~h}$ during the cold season. Precipitation probability skills for the warm season show generally lower scores, but more variability between cities. The scores found are similar

TABLE 5. Absolute value of forecast and climatological control errors for the 1984-85 cold season for point and area-averaged QPFs. Units of these errors are in categories, as defined in the text. The number of forecasts in each category is represented by $N$. Total skill for each forecast range is found by using the total forecast and control error points in Eq. (1).

\begin{tabular}{|c|c|c|c|c|c|c|c|c|c|c|c|c|}
\hline \multirow{2}{*}{$\begin{array}{l}\text { Forecast } \\
\text { range }\end{array}$} & \multicolumn{3}{|c|}{$0-12 \mathrm{~h}$} & \multicolumn{3}{|c|}{$12-24 \mathrm{~h}$} & \multicolumn{3}{|c|}{$24-36 \mathrm{~h}$} & \multicolumn{3}{|c|}{$36-48 \mathrm{~h}$} \\
\hline & $N$ & Forecast & Control & $N$ & Forecast & Control & $N$ & Forecast & Control & $N$ & Forecast & Control \\
\hline
\end{tabular}

(a) Summary of eight city point precipitation forecasts

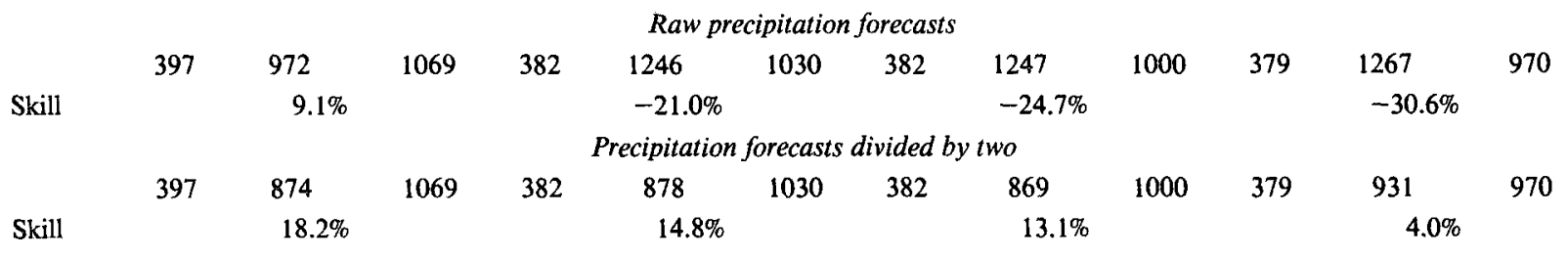

(b) Summary of area-averaged forecasts of four regions

Region

\begin{tabular}{|c|c|c|c|c|c|c|c|c|c|c|c|c|}
\hline \multicolumn{13}{|c|}{ Raw precipitation forecasts } \\
\hline $\begin{array}{l}1 \\
2 \\
3 \\
4\end{array}$ & $\begin{array}{l}48 \\
78 \\
47 \\
95\end{array}$ & $\begin{array}{r}80 \\
119 \\
65 \\
144\end{array}$ & $\begin{array}{r}114 \\
157 \\
96 \\
193\end{array}$ & $\begin{array}{l}47 \\
76 \\
43 \\
95\end{array}$ & $\begin{array}{r}113 \\
135 \\
89 \\
167\end{array}$ & $\begin{array}{r}109 \\
146 \\
91 \\
188\end{array}$ & $\begin{array}{l}46 \\
76 \\
43 \\
94\end{array}$ & $\begin{array}{l}131 \\
167 \\
102 \\
159\end{array}$ & $\begin{array}{r}111 \\
138 \\
87 \\
180\end{array}$ & $\begin{array}{l}46 \\
76 \\
46 \\
92\end{array}$ & $\begin{array}{l}152 \\
161 \\
103 \\
201\end{array}$ & $\begin{array}{r}113 \\
138 \\
94 \\
175\end{array}$ \\
\hline Total & 268 & 408 & 560 & 261 & 504 & 534 & 259 & 559 & 516 & 260 & 617 & 520 \\
\hline Skill & & $27.1 \%$ & & & 5.6 & & & -8.3 & & & -18 & \\
\hline \multicolumn{13}{|c|}{ Precipitation forecasts divided by two } \\
\hline $\begin{array}{l}1 \\
2 \\
3 \\
4\end{array}$ & $\begin{array}{l}48 \\
78 \\
47 \\
95\end{array}$ & $\begin{array}{r}85 \\
151 \\
87 \\
185\end{array}$ & $\begin{array}{r}114 \\
157 \\
96 \\
193\end{array}$ & $\begin{array}{l}47 \\
76 \\
43 \\
95\end{array}$ & $\begin{array}{r}86 \\
123 \\
61 \\
153\end{array}$ & $\begin{array}{r}109 \\
146 \\
91 \\
188\end{array}$ & $\begin{array}{l}46 \\
76 \\
43 \\
94\end{array}$ & $\begin{array}{r}90 \\
116 \\
76 \\
147\end{array}$ & $\begin{array}{r}111 \\
138 \\
87 \\
180\end{array}$ & $\begin{array}{l}46 \\
76 \\
46 \\
92\end{array}$ & $\begin{array}{r}98 \\
135 \\
92 \\
168\end{array}$ & $\begin{array}{r}113 \\
138 \\
94 \\
175\end{array}$ \\
\hline Total & 268 & 508 & 560 & 261 & 423 & 534 & 259 & 429 & 516 & 260 & 493 & 520 \\
\hline Skill & & $9.3 \%$ & & & 20. & & & 16. & & & & \\
\hline
\end{tabular}




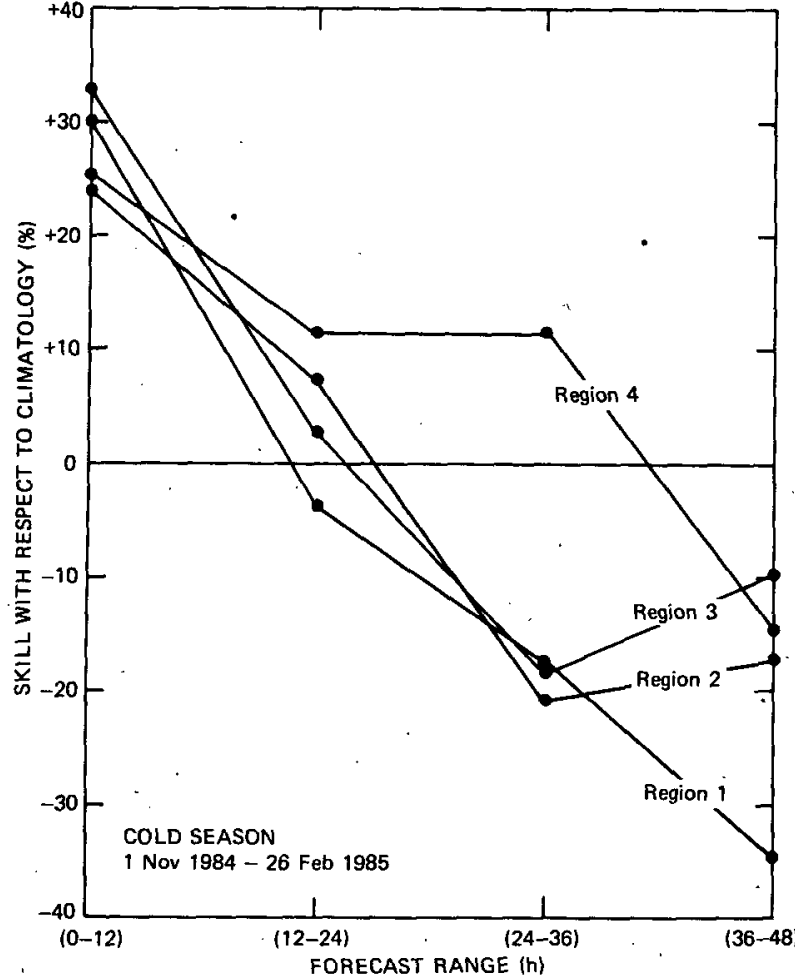

FIG. 7. As in Fig. 5 except that area-averaged precipitation forecasts are assessed for each of the four regions shown in Fig. 1.

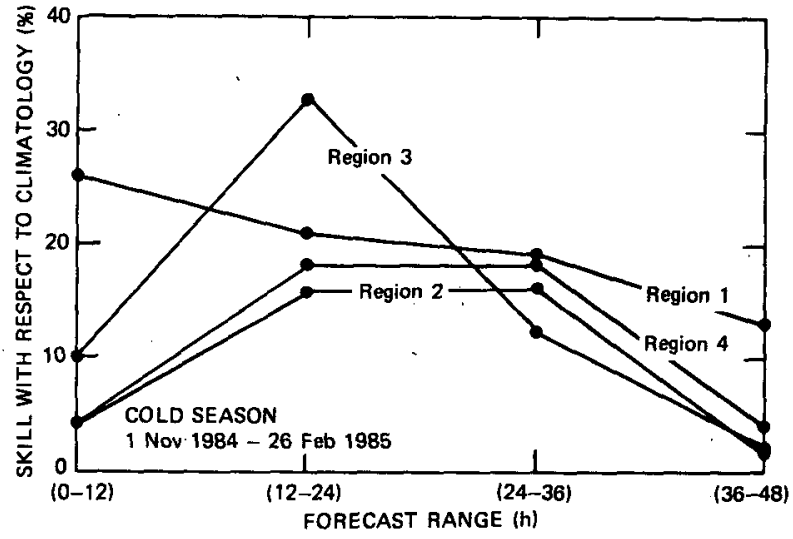

FIG. 8. As in Fig. 7 except that the forecasted precipitation amounts have been halved.

to those found by Bosart (1983) and Sanders (1986) for the eastern United States locations of Albany and Boston.

No obvious geographical bias can be found in either the precipitation probability or quantitative precipitation forecasts. We might have speculated in advance of this study that precipitation forecasting for a city such as Seattle would be more difficult than forecasting for Boston, because Seattle is located to the east of the data-sparse Pacific Ocean. However, our study suggests

TABLE 6. As in Table 5 except for forecasts during the period 11 June-19 July 1984.

\begin{tabular}{|c|c|c|c|c|c|c|c|c|c|c|c|}
\hline \multirow{2}{*}{$\begin{array}{l}\text { Forecast } \\
\text { range }\end{array}$} & \multicolumn{2}{|c|}{$0-12 \mathrm{~h}$} & \multicolumn{3}{|c|}{$12-24 \mathrm{~h}$} & \multicolumn{3}{|c|}{$24-36 \mathrm{~h}$} & \multicolumn{3}{|c|}{$36-48 \mathrm{~h}$} \\
\hline & Forecast & Control & $N$ & Forecast & Control & $N$ & Forecast & Control & $N$ & Forecast & Control \\
\hline
\end{tabular}

(a) Summary of eight city point precipitation forecasts

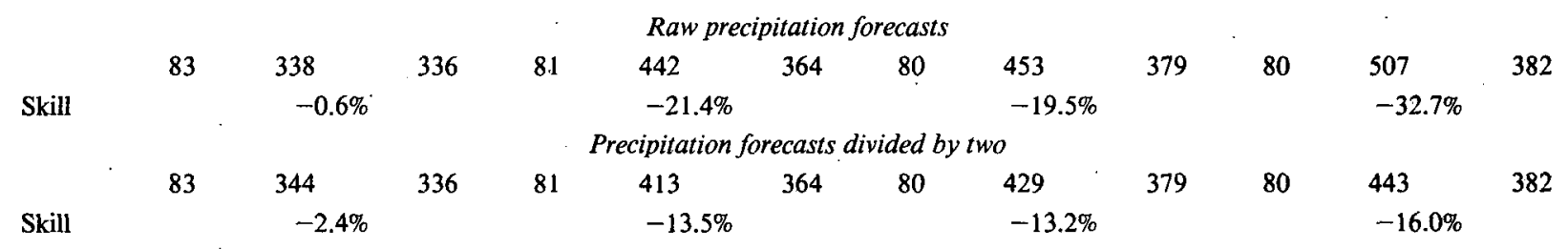

(b) Summary of area-averaged forecasts of four regions

Region

\begin{tabular}{|c|c|c|c|c|c|c|c|c|c|c|c|c|}
\hline \multicolumn{13}{|c|}{ Raw precipitation forecasts } \\
\hline $\begin{array}{l}1 \\
2 \\
3 \\
4\end{array}$ & $\begin{array}{r}18 \\
14 \\
16 \\
7\end{array}$ & $\begin{array}{l}47 \\
37 \\
87 \\
20\end{array}$ & $\begin{array}{l}58 \\
21 \\
66 \\
15\end{array}$ & $\begin{array}{r}19 \\
16 \\
17 \\
5\end{array}$ & $\begin{array}{l}97 \\
52 \\
99 \\
14\end{array}$ & $\begin{array}{l}92 \\
26 \\
74 \\
12\end{array}$ & $\begin{array}{r}19 \\
14 \\
13 \\
5\end{array}$ & $\begin{array}{r}103 \\
50 \\
70 \\
16\end{array}$ & $\begin{array}{l}95 \\
29 \\
55 \\
12\end{array}$ & $\begin{array}{l}22 \\
11 \\
15 \\
8\end{array}$ & $\begin{array}{l}86 \\
61 \\
90 \\
34\end{array}$ & $\begin{array}{l}82 \\
17 \\
59 \\
26\end{array}$ \\
\hline Total & 55 & 191 & 160 & 57 & 262 & 204 & 51 & 239 & 191 & 56 & 271 & 184 \\
\hline Skill & & $-19.4 \%$ & & & -28 & & & -25 & & & -47 & \\
\hline \multicolumn{13}{|c|}{ Precipitation forecasts divided by two } \\
\hline $\begin{array}{l}1 \\
2 \\
3 \\
4\end{array}$ & $\begin{array}{r}18 \\
14 \\
16 \\
7\end{array}$ & $\begin{array}{l}61 \\
39 \\
93 \\
21\end{array}$ & $\begin{array}{l}58 \\
21 \\
66 \\
15\end{array}$ & $\begin{array}{r}19 \\
16 \\
17 \\
5\end{array}$ & $\begin{array}{r}102 \\
53 \\
97 \\
15\end{array}$ & $\begin{array}{l}92 \\
26 \\
74 \\
12\end{array}$ & $\begin{array}{r}19 \\
14 \\
13 \\
5\end{array}$ & $\begin{array}{l}95 \\
45 \\
76 \\
17\end{array}$ & $\begin{array}{l}95 \\
29 \\
55 \\
12\end{array}$ & $\begin{array}{r}22 \\
11 \\
15 \\
8\end{array}$ & $\begin{array}{l}87 \\
44 \\
84 \\
34\end{array}$ & $\begin{array}{l}82 \\
17 \\
59 \\
26\end{array}$ \\
\hline Total & 55 & 214 & 160 & 57 & 267 & 204 & 51 & 233 & 191 & 56 & 249 & 184 \\
\hline Skill & & $-33.8 \%$ & & & -30 & & & -22 & & & -35 & \\
\hline
\end{tabular}




\begin{tabular}{|c|c|c|c|c|}
\hline Station & $\begin{array}{l}\text { Forecast } \\
\text { range }(\mathrm{h})\end{array}$ & $N$ & Mean & $\begin{array}{l}\text { Standard } \\
\text { deviation }\end{array}$ \\
\hline BOS & $\begin{array}{r}0-12 \\
12-24 \\
24-36 \\
36-48\end{array}$ & $\begin{array}{l}11 \\
12 \\
11 \\
13\end{array}$ & $\begin{array}{l}-0.7 \\
-1.9 \\
-0.2 \\
-2.3\end{array}$ & $\begin{array}{r}3.6 \\
7.6 \\
12.3 \\
9.3\end{array}$ \\
\hline$A L B$ & $\begin{array}{r}0-12 \\
12-24 \\
24-36 \\
36-48\end{array}$ & $\begin{array}{l}13 \\
14 \\
15 \\
17\end{array}$ & $\begin{array}{r}-1.8 \\
-0.6 \\
0.3 \\
-1.1\end{array}$ & $\begin{array}{l}5.4 \\
9.7 \\
5.9 \\
7.5\end{array}$ \\
\hline ORD & $\begin{array}{r}0-12 \\
12-24 \\
24-36 \\
36-48\end{array}$ & $\begin{array}{r}8 \\
* 7 \\
6 \\
7\end{array}$ & $\begin{array}{r}-5.0 \\
-5.9 \\
-10.0 \\
-6.3\end{array}$ & $\begin{array}{r}7.3 \\
6.3 \\
11.0 \\
8.3\end{array}$ \\
\hline DAY & $\begin{array}{r}0-12 \\
12-24 \\
24-36 \\
36-48\end{array}$ & $\begin{array}{r}* 10 \\
14 \\
15 \\
11\end{array}$ & $\begin{array}{r}-3.4 \\
-2.1 \\
-2.2 \\
0.2\end{array}$ & $\begin{array}{l}4.5 \\
5.9 \\
6.9 \\
8.9\end{array}$ \\
\hline DSM & $\begin{array}{r}0-12 \\
12-24 \\
24-36 \\
36-48\end{array}$ & $\begin{array}{r}* 18 \\
* 16 \\
* 16 \\
16\end{array}$ & $\begin{array}{l}-5.3 \\
-5.9 \\
-4.8 \\
-4.8\end{array}$ & $\begin{array}{r}8.0 \\
9.1 \\
7.8 \\
10.3\end{array}$ \\
\hline STL & $\begin{array}{r}0-12 \\
12-24 \\
24-36 \\
36-48\end{array}$ & $\begin{array}{r}11 \\
10 \\
9 \\
8\end{array}$ & $\begin{array}{l}-3.3 \\
-3.6 \\
-4.4 \\
-3.4\end{array}$ & $\begin{array}{l}7.8 \\
8.4 \\
7.9 \\
9.6\end{array}$ \\
\hline SEA & $\begin{array}{r}0-12 \\
12-24 \\
24-36 \\
36-48\end{array}$ & $\begin{array}{r}5 \\
2 \\
2 \\
* 4\end{array}$ & $\begin{array}{l}-3.8 \\
-8.0 \\
-7.5 \\
-9.3\end{array}$ & $\begin{array}{l}4.4 \\
8.0 \\
4.5 \\
5.0\end{array}$ \\
\hline GEG & $\begin{array}{r}0-12 \\
12-24 \\
24-36 \\
36-48\end{array}$ & $\begin{array}{l}7 \\
6 \\
6 \\
4\end{array}$ & $\begin{array}{l}-1.0 \\
-0.8 \\
-1.0 \\
-1.5\end{array}$ & $\begin{array}{l}1.7 \\
2.3 \\
1.8 \\
2.7\end{array}$ \\
\hline
\end{tabular}

otherwise. Indeed, experiments conducted at the University of Illinois Department of Atmospheric Sciences during the past three semesters have shown that the MOS skills in predicting measurable precipitation at Seattle have continued to be as high as those found in this study, and have been typically higher than those predictions for Urbana, Illinois, Raleigh-Durham, North Carolina and Tampa, Florida. One might hypothesize that our being able to define only synopticscale, upper-tropospheric mobile troughs in the eastern Pacific gives us enough information to predict precipitation at Seattle acceptably. These troughs are typically well defined by the wealth of commercial aircraft data and by satellite imagery in the eastern Pacific. Clearly, more work is necessary to pinpoint what data requirements are necessary for successfully predicting precipitation at a given location.

While our ability to distinguish between dry and rainy days appears high, a substantial minority (about $15 \%$ ) of the precipitation probability forecasts in our cold-season sample contain errors in excess of 0.5 . We find that in all seven cities examined, an unexpectedly large number of these forecasts involve observed measurable precipitation. Thus, the number of false alarm forecasts is unexpectedly small. We had too few cases to examine such biases in our warm-season sample.

The point quantitative precipitation forecasts for the cold season show a clear loss of skill beyond a $12 \cdot \mathrm{h}$ forecast range. We find that much of this loss of skill is associated with a statistically significant tendency for the LFM to overpredict precipitation amounts. Areaaveraged QPFs lose to the climatological control forecast beyond a 24 -h forecast range. Bosart (1980) has found comparable skill scores and the same tendency to overpredict precipitation in the LFM-2 forecasts.

However, in order to account for a coding error in the LFM precipitation algorithm, we divided all precipitation forecasts by 2 , and recomputed the skill scores and biases. The exercise has revealed a remarkable improvement in the QPF skills such that overall cold-season point quantitative precipitation forecasts are a respectable $18.2,14.8,13.1$ and $4.0 \%$ for the respective forecast ranges of $0-12,12-24,24-36$ and $36-$ $48 \mathrm{~h}$. Area-averaged forecasts using the same correction show generally improved skills of 9.3,20.8, 16.9 and $5.2 \%$ for the same forecast ranges. While the corrected forecasts tend to produce statistically significant underforecasting of precipitation, these biases are associated with gains over the climatological control forecasts.

The summer quantitative precipitation results show a loss of skill against climatology for both point and area-averaged forecasts from both the raw and halved data. Systematic underprediction of warm-season precipitation events has been established for both point and area-averaged uncorrected forecasts. Naturally, when the forecasts are divided by 2 , the systematic underprediction is enhanced and the skill is reduced to even lower values than are shown for the raw precipitation forecasts.

Thus, it appears that major improvements need to be made in the warm-season, typically convective, precipitation events, since little usefulness can be found in the current LFM model QPFs. However, the coldseason precipitation forecasts, when corrected to values $50 \%$ of what is currently displayed, show positive skill against the climatological control out to a 48-h range. These corrected precipitation forecasts show no evidence of the cold-season overprediction bias that we find in our raw statistics or that Bosart (1980) found in his study. While these corrected skills are not as high as we have found for precipitation probabilities, the base upon which improvements can be made is considerably higher than had previously been found.

Acknowledgments. The authors wish to express gratitude to Professors Cliff Mass and Lance Bosart for graciously supplying us with supplementary data necessary for completing this project. Appreciation is also extended to Mr. Ron Widitz in programming assis- 
tance, and to Mr. Earl Barker for his invaluable aid in collecting data. John Brother drafted the figures and Mrs. Norene McGhiey typed the manuscript. This research has been supported by the National Science Foundation under Grants ATM-8305096 and ATM8516263 .

\section{REFERENCES}

Bengtsson, L., 1985: Medium-range forecasting: The experience of ECMWF. Bull. Amer. Meteor. Soc., 66, 1133-1146.

Bosart, L. F., 1980: Evaluation of LFM-2 quantitative precipitation forecasts. Mon. Wea. Rev., 108, 1087-1099.

$\ldots$, 1983: An update on trends in skill of daily forecasts of temperature and precipitation at the State University of New York at Albany. Bull. Amer. Meteor. Soc., 64, 346-354.

Brier, G. W., 1950: Verification of forecasts expressed in terms of probability. Mon. Wea. Rev., 78, 1-3.

Charba, J. P., and W. H. Klein, 1980: Skill in precipitation forecasting in the National Weather Service. Bull. Amer. Meteor. Soc., 61, 1546-1555.

Gerrity, J. F., 1977: The LFM model-1976: A documentation. NOAA Tech. Memo NWS NMC-60. [Available from the National Meteorological Center, World Weather Building, Washington DC 20233; NTIS Rep. No. PB-279-419.]

Glahn, H. R., 1985: Yes, precipitation forecasts have improved. Bull. Amer. Meteor. Soc., 66, 820-830.

Gyakum, J. R., 1986: Experiments in temperature and precipitation forecasting for Illinois. Wea. Forecasting, 1, 77-88.

Hoke, J. E., N. A. Phillips, G. J. DiMego and D. G. Deaven, 1985:
NMC's regional analysis and forecast system-results from the first year of daily, real-time forecasting. Preprints, Seventh Conf. on Numerical Weather Prediction, Montreal, Amer. Meteor. Soc., 444-451.

Klein, W. H., and F. Lewis, 1970: Computer forecasts of maximum and minimum temperatures. J. Appl. Meteor., 9, 350-359.

Murphy, A. H., and T. E. Sabin, 1986: Trends in the quality of National Weather Service forecasts. Wea. Forecasting, 1, 4255.

Newell, J. E., and D. G. Deaven, 1981: The LFM II model-1980. NOAA Tech. Memo NWS-66. [Available from the National Meteorological Center, World Weather Building, Washington, DC 20233; NOAA S/T 18-121.]

NOAA, 1963-83: Climatological Data (State), Environmental Data and Information Service. [Available from National Climatic Center, Asheville, NC 28801-2696.]

Panofsky, H. A., and G. W. Brier, 1968: Some Applications of Statistics to Meteorology. The Pennsylvania State University, 224 pp.

Phillips, N. A., 1985: Pre-implementation results from the regional analysis and forecast system (RAFS). NWS Tech. Procedures Bull. No. 350, NOAA, Washington, DC, 13 pp. [A vailable from the National Weather Service Program Requirements and Planning Division, Silver Spring, MD 20910.]

Ramage, C. S., 1982: Have precipitation forecasts improved? Bull. Amer. Meteor. Soc., 63, 739-743.

Sanders, F., 1979: Trends in skill of daily forecasts of temperature and precipitation, 1966-78. Bull. Amer. Meteor. Soc., 60, 763769.

- 1986: Trends in skill of Boston forecasts made at MIT, 196684. Bull. Amer. Meteor. Soc., 67, 170-176. 